\title{
Reducing Phytic Acid from Sudanese Sorghum Bicolor (F.G) Using Simple Technique Methods
}

\author{
Omar Eltyeb Omara Ahmed (Ph. D) \\ Sudan University of Sciences and Technology, Graduate Collage, Faculty of Agriculture Studies, Sudan \\ *Corresponding Author: Dr. Omar Eltyeb Omara Ahmed, Sudan University of Sciences and Technology, \\ Graduate Collage, Faculty of Agriculture Studies, Sudan
}

\begin{abstract}
An Experiment was conducted to reduce phytic acid from Sudanese Sorghum bicolor local name Feterita Gadarif (F.G) using a simple technique method. Approximate Analysis was done to determine the nutrition value of the grains before and after processing methods, to measure the change of nutrient content after processing treatments. The treatments of processing were divided into five methods of process, in addition of control (unprocessed cereal) such as dehulling, germination, soaking, vitamin $C$ and storing methods respectively to reduce phytic acid content of the grains. The treatments shown significant decrease ( $p>0.05)$ in phytic acid contents of the processed sorghum as compared with unprocessed one (control). The highest loss of phytate registered in germination method (98\%) followed by vitamin C treatment (86.2\%), soaking (78.6\%), storing (59.6) and dehulling method respectively. There were a significant increase ( $p>0.05$ ) in metabolic energy. $\mathrm{Ca}, \mathrm{Fe}$ and $\mathrm{P}$ of cereal nutrients content, obtained after processing operation by method of germination and some slight decrease of protein content of all processed grains
\end{abstract}

Keywords: phytic acid, determination, processing methods, germination

\section{INTRODUCTION}

Food crops such as cereals, legumes and oilseeds are grown in over $90 \%$ of the world. Foods derived from these crops provide major source nutrients to mankind; one of these crops is sorghum bicolor, which is used for both animals and humans. Sorghum originated in northern Africa, which is used largely in world and over 300 million people depend on it. The cereals are rich in minerals but, the bio-availability of these minerals is usually low because of the presence of anti nutrition factors such as phytic acid (Valencia et al 1999), is an important constituent of sorghum. When Phytic acid or Phytate is discovered in salt form in 1903 Edward et al (2012), Phytic acid has been termed as antinutrient, due to its ability to bind minerals protein and starches, either directly or indirectly and thus alter their soluble functionality and absorption (Nelson, 1967). The effect on nutrition due to phytic acid in human and animals is related to the interaction of phytic acid with proteins, vitamins, and several minerals, thereby restricting their bio-extractability (Svanberg and Lorri. 1997). In the view of anti nutritional effects of phytic acid, many attempts have been made to reduce phytate

Therefore, the present study was conducted to use simple processing methods such as milling, soaking, germination, vitamin $\mathrm{C}$ and storing, to reduce phytic acid compound from sorghum and to shed light on phytic acid as a controversial component.

\section{MAterials AND Methods}

Sudanese Sorghum, Sorghum bicolor (Fatareta Gadarif) was purchased from Gadarif State local market of about $20 \mathrm{~kg}$, for the experimental purpose which was cleaned out of damaged seeds and foreign objects. Then subject is processed to five treatments using a simple technique to reduce phytic acid, such as milling, soaking, germination, vitamin $\mathrm{C}$ and storing in addition to control (UN processed sorghum).

Chemical composition of sorghum were analyzed before and after processing treatment to determine nutrients content and phytic acid in the grain 


\subsection{Chemical Composition of Unprocessed Sorghum (F G )}

The seeds were cleaned manually to remove broken seeds, dust, and other extraneous materials. The cleaned grains were milled into fine flour with hammer mill (Gibbons Electric, Essex K) to pass $0.4 \mathrm{~mm}$ mesh size screen and were stored at $4 \mathrm{C}$ before being used for their analysis. The seeds were chemically analyzed according to procedure of AOAC (1980) .The sorghum protein content were determined by adopting standard AOAC(1995) method. Energy was calculated as described by Osbonrne and Voogt (1978). Minerals were determined in the sample by dry-ashing methods, described by Chapman and Pratt (1961). The amount of iron was determined using atomic absorption spectroscopy (Perkin-Elmer 2380). Ammonium vanadate method of Chapman and Pratt (1982). Calcium was determined by a titration method described by Chapman and Pratt (1961), hydrochloric acid extractability of minerals was performed according to the Chapman and Mahjan (1988).

\subsection{Phytic Acid determination}

Phytic acid was determined by the method described by Wheeler and Ferrel (1971) using 2.0g dried sample. A standard curve was prepared expressing the results as $\mathrm{Fe}$ (No) 3 equivalents, phytate phosphorus were calculated from the standard curve assuming a 4:6iron to phosphorus molar ratio

\subsection{Processing Treatment}

2.3.1. Dehuling $5.0 \mathrm{~kg}$ of cleaned cereals, moistened by adding water before hulling, to softening the surface of the grain and facilitating detachment of the pressure inside the machine. The commercial machine combines two stages, they are dehulling and milling. The grain was passed through the machine capacity of around 200to $275 \mathrm{~kg} / \mathrm{h}$ for hulling, yield about $78 \%$. The hulling grains were milled into fine flour with hammer mill (Gibbons Electric, Essex K) to pass $0.4 \mathrm{~mm}$ mesh size screen and were stored at $4 \mathrm{C}$ before being used for their analysis. The seed flour was chemically analyzed according to procedure of AOAC (1980). The sorghum protein content was determined by adopting standard AOAC (1995) method. Energy was calculated as described by Osbonrne and Voogt (1978). Minerals were determined in the sample by the dryashing methods, described by Chapman and Pratt (1961). Phytic acid was determined by the method, described by Wheeler and Ferrel (1971) using $2.0 \mathrm{~g}$ dried sample.

2.3.2. Soaked $5 \mathrm{~kg}$ of the whole cleaned seeds was put in a pot filled with tap water, The grains were removed from the water after 12 hours sun -dried, then milled into a fine flour with hammer mill (Gibbons Electric ,Essex K ) to pass $0.4 \mathrm{~mm}$ mesh size screen and were stored at 4C before being used for their analysis. The processed seed flour were chemically analyzed according to procedure of AOAC (1980). The processing of sorghum protein content was determined by adopting standard AOAC(1995) method. Energy was calculated as described by Osbonrne and Voogt (1978). Minerals were determined in the sample by dry-ashing methods, described by Chapman and Pratt (1961). Phytic acid was determined by the method described by Wheeler and Ferrel (1971) using 2.0g dried sample. Then $2 \mathrm{ml}$ of the mill dried sample was weighted to determine phytic acid.

2.3.3. Germination According to the method of Koua Kou et al (2008). $3 \mathrm{~kg}$ of the whole cleaned seeds was immersed in water overnight. The grains were spread on trays lined with cloth. It was kept wet by frequent spraying water. After 96 hours, the germinated grains were removed from the trays, sun -dried, then milled into fine flour with hammer mill (Gibbons Electric, Essex K ) to pass $0.4 \mathrm{~mm}$ mesh size screen and were stored at $4 \mathrm{C}$ before being used for their analysis. The processed seed flour was chemically analyzed according to procedure of AOAC (1980). The processing sorghum protein content was determined by adopting standard AOAC (1995) method. Energy was calculated as described by Osbonrne and Voogt (1978). Minerals were determined in the sample by dry-ashing methods described by Chapman and Pratt (1961). Phytic acid was determined by the method described by Wheeler and Ferrel (1971), using 2.0g dried sample. Then $2 \mathrm{ml}$ of the dried milled sample was weighted to determined phytic acid.

2.3.4. Vitamin $\mathrm{C}$ added $1 \mathrm{~kg}$ of the whole cleaned seeds was milled in a laboratory mill to obtain fine flour, 150mg of ascorbic acid was mixed with the sample, then the processed seed flour were chemically analyzed according to procedure of AOAC (1980). The processing sorghum protein 
content was determined by adopting standard AOAC (1995) method. Energy was calculated as described by Osbonrne and Voogt (1978). Minerals were determined in the sample by dryashing methods described by Chapman and Pratt (1961). Phytic acid was determined by the method described by Wheeler and Ferrel (1971), using 2.0g dried sample. Then $2 \mathrm{ml}$ of the milled dried sample were weighted to determined phytic acid.

2.3.5. Storing Sorghum cereal (fetareta gadarif) were stored for 12 month , $2 \mathrm{~kg}$ of the seeds then milled into fine flour with hammer mill (Gibbons Electric ,Essex K ) to pass $0.4 \mathrm{~mm}$ mesh size screen and were stored at 4C before being used for their analysis, the processed seed flour were chemically analyzed according to procedure of AOAC (1980). The processing sorghum protein content were determined by adopting standard AOAC(1995) method . Energy was calculated as described by Osbonrne and Voogt (1978). Minerals were determined in the sample by the dry-ashing methods described by Chapman and Pratt (1961). Phytic acid was determined by the method described by Wheeler and Ferrel (1971) using $2.0 \mathrm{~g}$ dried sample...Then $2 \mathrm{ml}$ of the milled dried sample were weighted to determined phytic acid.

\subsection{Statistical Analysis}

Each sample was analyzed in triplicate and the values were then averaged. Data were assessed by the analysis of variance (ANOVA) as described by Snedecor and Cochran (1987) and by Duncanmultiple range test at probability of $p<0.05$.

\section{RESUltS}

3.1. Results of the proximate analysis of minerals and calculated energy of the sorghum (F. G) are present in table (1) and (2). The result indicated that sorghum (F. G) had a high percentage of crude protein, Ether Extract and metabolizable energy.

Table1. Chemical composition of sorghum (F.G)\%

\begin{tabular}{|l|l|}
\hline Chemical profile & Sorghum(F.G) \\
\hline Dry matter & 93.83 \\
\hline Crude protein & 14.3 \\
\hline Ether Extract & 4.58 \\
\hline Crud fiber & 2.69 \\
\hline Nitrogen free extract & 7.31 \\
\hline Metabolizable energy (Kcal/kg ) & 383 \\
\hline Methionin & $8.5 \mathrm{mg} / 100 \mathrm{~g}$ \\
\hline Thiamin & $0.38 \mathrm{mg} / 100 \mathrm{~g}$ \\
\hline Lysine & $117.6 \mathrm{mg} / 100 \mathrm{~g}$ \\
\hline Niacin & $3.8 \mathrm{mg} / 100 \mathrm{~g}$ \\
\hline
\end{tabular}

Analyzed values are means of duplicate sample. ME is calculated value by the equation of Carpenter and Clegg (1966).-NFE is calculated value.

Table2. Minerals content of sorghum bicolor (F.G) $\mathrm{mg} / 100 \mathrm{~g}$

\begin{tabular}{|l|l|}
\hline \multicolumn{1}{|c|}{ Chemical profile } & \multicolumn{1}{c|}{ Sorghum(F.G) } \\
\hline $\mathrm{Ca}$ & 12.8 \\
\hline $\mathrm{P}$ & 356 \\
\hline $\mathrm{Mg}$ & 103 \\
\hline $\mathrm{Fe}$ & 4.8 \\
\hline $\mathrm{Mn}$ & 122 \\
\hline
\end{tabular}

Analyzed values are means of duplicate sample.

ME is calculated value by the equation of Carpenter and Clegg (1966).

NFE is calculated value.

3.2. Chemical composition of sorghum before and after processing were shown in table (3), the result shown significant $(\mathrm{p}>0.05)$ change in some nutrient value of processed grains in energy, $\mathrm{Ca}, \mathrm{P}$, and $\mathrm{Fe}$, and slight change in protein content. 
Reducing Phytic Acid from Sudanese Sorghum Bicolor(F.G) Using Simple Technique Methods

Table3. Effect of treatments on sorghum chemical composition before and after processing

\begin{tabular}{|l|l|l|l|l|l|l|}
\hline Treatments & CP & Energy (kcal/kg) & Ca & P & Fe & Phytate \\
\hline Raw sorghum & 145.30 & $3100.50 b^{*}$ & $0.260 \mathrm{a}$ & $0.38 \mathrm{a}$ & $4.80 \mathrm{a}$ & $889.20 \mathrm{a}$ \\
\hline Dehulling & 143.00 & $3101.00 \mathrm{~b}$ & 0.252 & $0.30 \mathrm{~b}$ & $3.26 \mathrm{~b}$ & $445.06 \mathrm{~b}$ \\
\hline Germination & 143.4 & $3113.33 \mathrm{a}$ & $0.265 \mathrm{a}$ & $0.28 \mathrm{~b}$ & $3.26 \mathrm{~b}$ & $87.90 \mathrm{~g}$ \\
\hline Soaking & 145.00 & $3100.67 \mathrm{~b}$ & 0.250 & $0.28 \mathrm{~b}$ & $4.83 \mathrm{a}$ & $189.70 \mathrm{e}$ \\
\hline Vitamin C & 145.10 & $3100.00 \mathrm{~b}$ & 0.250 & $0.29 \mathrm{~b}$ & $4.90 \mathrm{a}$ & $122.40 \mathrm{f}$ \\
\hline Storing & 143.00 & $398.20 \mathrm{c}$ & 0.245 & $0.28 \mathrm{~b}$ & $3.30 \mathrm{~b}$ & $360.00 \mathrm{c}$ \\
\hline Overall mean & 144.13 & 2652.28 & 0.254 & $0.30 \mathrm{~b}$ & $4.06 \mathrm{a}$ & $336.94 \mathrm{~d}$ \\
\hline Standard Error (SE \pm$)$ & 0.71 & 2.85 & 0.01 & 0.01 & 0.25 & 1.52 \\
\hline LSD $_{0.05}$ & $\mathrm{~ns}$ & 8.70 & Ns & 0.03 & 0.77 & 4.68 \\
\hline
\end{tabular}

LSD 0.05 : least significant difference at 0.05 level of significance (for mean separations and comparisons)

* Different small letters represent significant differences between treatments means in each column.

Mean squares (from analysis of variance (ANOVA) table) for effect of different treatments on sorghum chemical composition before and after processing

\begin{tabular}{|l|l|l|l|l|l|l|l|}
\hline Source of variation & Degree of freedom (d.f) & CP & Energy & Ca & P & Fe & Phytate \\
\hline Treatments & 5 & 3.6253 & 465.83 & 0.00016 & 0.0048 & 2.2189 & 293.0241 \\
\hline Experimental Error & 12 & 1.4961 & 24.339 & 0.000047 & 0.00022 & 0.1956 & 6.9239 \\
\hline F-calculated value & & 2.4230 & 19.14 & 3.53 & 21.45 & 11.58 & 42.753 \\
\hline Level of Significance & Ns & $* * *$ & $*$ & $* * *$ & $* * *$ & $* * *$ \\
\hline $\begin{array}{l}\text { Coefficient } \\
\text { variation (C.V.\%) }\end{array}$ & & 8.50 & 1.86 & 2.70 & 4.94 & 10.89 & 7.81 \\
\hline
\end{tabular}

N. s: not significant at 0.05 level of significance

\subsection{Determination of Phytic Acid}

Results of determination of phytic acid in raw sorghum and processed sorghum (F.G) are present in table (4). The result indicated a significant decrease $(p>0.05)$ of phytic acid of all the processed treatments.

Table4. Effect of treatments on sorghum phytate $\mathrm{mg} / 100 \mathrm{~g}$ before and after processing

\begin{tabular}{|l|l|l|}
\hline Treatments & Phytic acid content & Loss\% \\
\hline Raw sorghum & $889.20 \mathrm{a}$ & 0 \\
\hline Dehuling & $445.20 \mathrm{~b}$ & 49.9 \\
\hline Germination & $87.90 \mathrm{~g}$ & 90.1 \\
\hline Soaking & $189.70 \mathrm{e}$ & 78.6 \\
\hline Vitamin C & $128.40 \mathrm{f}$ & 86.2 \\
\hline Storing & $360.00 \mathrm{c}$ & 59.6 \\
\hline
\end{tabular}

LSD 0.05: least significant difference at 0.05 level of significance (for mean separations and comparisons)

* Different small letters represent significant differences between treatments means in each column.

\section{DISCUSSION}

\subsection{Chemical Composition}

The moisture content of sorghum bicolor (F.G) was in the range obtained by AbdElnour (2001) who indicated that moisture content of Feterita and Dabar was 9.6-8.75 respectively. The crude protein content of sorghum bicolor

(F.G ) ( Table 3 ) was in the range observed by Hulse et al (1980) who found that the protein content of sorghum bicolor ranged between 8-16 \% ,but lower than Elsayed (1999) analyzed the protein content of Tabat and Fetarita was 6.46-9.11, but higher than the value reported by Dillon ( 2007 ), and lower than that obtained by Mayada (2009).The metabolizable energy of sorghum ( F.G ) was in the range detected by Idris (2004) who found the carbohydrates content for sorghum was 80.7\%.Minerals content was in range optimum by Hulse et al (1980) and Idris (2004) 


\subsection{Phytic Acid in Unprocessed Grains}

The phytic acid content of sorghum (F.G ) ( Table4 ) are close to those reviewed by Marfo et al (1990) who reported that phytic acid content of red sorghum was 886mg /100g. Greiner (2006) and Konietzny and Koyode (2006) whom found that sorghum phytate ranged from 590 to 1180 and from 400 to $3500 \mathrm{mg} / 100 \mathrm{~g}$ dwt. The result was high than the range obtained by Eammambux et al ( 2009 ), and high than the range reported by Makokha et al ( 2002 ), also high than the found reported by Sathe (2002), these can be explained by that phytic acid content varied, stage of maturity , climatic, condition s type of soil, amount of available phosphorous and milling fraction of the grains

\subsection{Removal of Phytate}

Table (4) shown the removal of phytate after processed treatments, the highest loss of phytate ( $>0.05$ ) obtained by germination method $(90.1 \%$ ) flowed by vitamin $\mathrm{C}$ method $(86.2 \%)$,soaking method (78.6\%),storing method (59.6\%) and dehulling method (49.9\%) respectively. In fact phytic acid in flour can be hydrolyzed by the enzyme phytase, and the optimum condition for phytase activity are $\mathrm{PH}$ range from 5.0 to 5.5 and temperature rang 50 to $55 \mathrm{c}$.Germination method in sorghum grains reduced phytate up t0 90.9 after 96h Wisal (2004). The obtained was on line with Abdelrahman et al (2007) who reported that germination increase part of both major and trace minerals and also reduced significantly the phytic acid, germination is more effective way to remove phytic acid, and germination in $80-90 £$ removed $92 \%$ of phytate and releases vitamins and make grains and seeds more digestible . Vitamin C method reduced (P.A) $86.2 \%$, vita C is strong enhancer of plant iron can overcome the inhibitors in plant foods. One study found that various doses of phytate reduced iron absorption by 10 to $50 \%$.But adding $50 \mathrm{mg}$ of vitamin $\mathrm{C}$ counteracted the phytate and adding $150 \mathrm{mg}$ of vitamin $\mathrm{C}$ increased iron absorption to almost 30\%, similarly, in the presence of a large dose of tannic acid , $100 \mathrm{mg}$ of vitamin C increased iron absorption from 2-8\% .Snedecor et al (1987) The results of soaked sorghum was in range of result obtained by Motz et al , (2001) who reported that soaking of maize for $1 \mathrm{~h}$ at room temperature already led to be reduction of phytic acid by $51 \%$, but lower than the report obtained by Mahgoub and Elhage (1998) whom reported that soaking of sorghum flour at room temperature for $24 \mathrm{~h}$ reducing phytic acid level by 16-21\%.The reduced of phytic acid using storing method was present in table ( 4 ) the result was in the same line with Sathe (2002), who reported that the decreased of phytic acid during storage from 0 to $65 \%$ in cereal according to temperature and humidity and from 2.5 to $76 \%$ in legume, and the reduction depend on the type of seeds, storage condition, and the age of the seeds

The processed of sorghum bicolor (F.G) by using five technical methods changed the nutrient values of the seeds after processing is shown in Table (3). The high content of crude protein metabolizable energy and fat obtained by germinated seeds, the result on line with many workers, they observed increase in proteins during germination of cereals, this increase could be attributed to a synthesis of enzymatic proteins by germination seeds . (W H O, 1998). Marero et al (1988) also reported that the increases in protein might be due to the fact some amino acids are produced in excess of the requirement during protein synthesis and these tend to accumulate in free amino acids pool. In the same line Koua kou et al (2008) indicated that the seeds of cereals during their germination develop a strong enzymatic activity. The results also in line with Ocheme and Chinma , (2007) who find that germination significantly increases the protein dry mater and ash content, while fat content and energy values of the flour sample showed a decrease, these protein increase not exceeding $14 \%$ of the starting protein content . This was found to be attributed to loss of dry weight through respiration during germination, in the same line Beal and Mehta (1985) reported that germination reducing up to $75 \%$ of phytate and increase phytase activity, but different from Martinez et al (1980) who reported that germination decreased the content of lysine and tryptophan and vitamin such as C, B, A and E

\section{REFERENCES}

[1] Abd Elnour , K.M .(200,).The Effect of decortications on wet milling and starch quality of sorghum and millet grain .M Sc, Thesis, faculty of Agric. University of Khartoum, Sudan

[2] Abdelrahman, S.M.H.B, Elmakki, W.H.Idris, A.B.Hasan, W.E.Babiker andA.H.El-Yinay.2007. Antinutritional factor content and hydrochloric acid extractability of minerals in pearl milet cultivars by germination. Int J, Food Sci Nutr, 58:6-17.

[3] Ahmed, E.F (1993) Comparative study of wet milling properties of some sorghum varieties Msc. Thesis, Faculty of Agric. University of Khartoum .Sudan 
[4] AOAC. (1995) Official Methods of Analysis Association of Official Analytical Chemists Washington, DC.

[5] Chapman H D and Pratt F. P 1982 Determination of Mineral titration of analysis for soils plants and water .Edition Agriculture Division .California University U.S.A pp 169-170

[6] Chapman, B.M and Mahjan, L.1988 Effect of Natural Fermentation on the Extractability of minerals from pearl millet flour. J food Sic 53 1576-1577.

[7] Chapman, H.D and Peatt,F.P1961.Ammonium Vandate molybdate Method for Determination of Phosphorus .Methods of analysis for soils plants and water .Edition Agriculture Division .California University .U.S.A PP184=203

[8] Chapman, H.D, and Pratt, F, P.1961.AmmoniumVandate-molybdate methods for Determination of Phosphorus, Methods of analysis for soil, plant and water. IEdition, Agriculture Division, California .University, U.S.A,pp,184-203

[9] Emmambux, M. Nandi Taylor, R.N (2009) Properties of heat -treat men ted sorghum and maize meal and their prolamin proteins .J .Agric, Food chem., 57, 1045-1050.

[10] Greiner R. Konietznyu (2005) Phytase for food Application .Food Techinol Biotechnol: 44, 125-140.

[11] Hulse. J. H: Laing E. M and Pearson, E (1980). Sorghum Millets: their composition and nutritive value. NewYork. Acadimic Press997p

[12] Idris, W.H (2004) Effect of processing on the anti-nutritional factors and minerals bio availability of sorghum PhD. Thesis. Faculty of Agric, University of Khartoum, Sudan.

[13] Kouakou, B. K, K. S. Alens, D. Alexis, D. Adjehi, D. K. Marcelin and G. Dago (2008). Biochemical changes occurring during germination and fermentation of millet and effect of technological processes on starch hydrolysis are due to the crude enzymatic extract of millet. J. Applied. Sci, RES 4:1502-1510

[14] Mahgoub, S.E.O and S.A.Elhage, 1998.Effect of milling soaking, malting heat treatment and fermentation on phytate level of flour Sudanese sorghum cultivars .food chem...61:77-80.

[15] Makokha A. O, Oniango R. K, Njoroges M, Kamaraok, (2002). Effect of traditional fermentation and malting on phytic acid and mineral availability from sorghum and finger millet grain varietirs grown in Kenya. University of Agriculture and Technology, department of food science. Journal Article Research Support-Non-U.S Govt

[16] Marfo. E. K, Simpson B. K, Idowu J. S and Oke. O. L (1990) Effect of local food processing of phytate level in cassava, cocoyam, yam, maize, sorghum, rice and soybean. J .Agric. Food Chem.38:1580-1585

[17] Martinez A. B, R. K, Simposon J. S, Idwu and R. Bressan, 1980. Relation of lysine and tryptophan to that of $\mathrm{Z}$, during germination of grain of corn and it is possible linkage with the growing cycle of the plant. Aresearch, Latinoam, Nutr, 30:607-633.

[18] Mullaney, Edward J: Ullah, Abul H. J: (2012) Phytase attributes-catalytic mechanisms and application. United State Department of Agriculture-.Agricultural Research Service. Retrieved May 18.2012

[19] Myada Alias Mustfa (2009). Evaluation of nutrient content of sorghum flour supplemented with wheat and pumpkin seed flour. MSc thesis. Faculty of Agricultural University of Khartoum Sudan

[20] Ocheme O. B and C. E. Chinma, 2008. Effect of soaking and germination on some physicochemical properties millet flour for porridge production $\mathrm{j}$. Food Technol, 6:185-188.

[21] Osbbome, D. R and Voogt, P 1978. Calculation of caloric value In Analysis of Nutrients in foods Academic Press New York pp 23-34

[22] Sathe, N. Rukma Reddy Shridhark (2002). Food Phytates. International Stander Book Number 1-5, 66768675, CRC Press, Boca Raton London New York Washington, D.C.

[23] Savanberg U and Lorri.W19987Fermintationand Nutrition Availability .food cont-8 319-327

[24] Siegenberg D, Baynes RD, Bothwell TH, Macfarlane BJ, Lamparelli RD ,Car NG, Macphail p, Schmidt U, Tal A, Mayet F . (1991). Ascorbic Acid prevents the dose dependent inhibitory effects of polyphenols and phytates on nonheme- iron absorption. Am. J .Clin .Nutr, Feb: 53(2):537-41.

[25] Snedecor G. W and W. G. Cochran (1987). Statistical Methods "Printing, The law State. University Press, Amcs, Jowa, U.S.A.

[26] T. S. Nelson (1967). The utilization of phytate -phosphorus by poultry: a review- poultry sci.46 pp862871.

[27] Valencia's, Svanberg U, Sandberg A. S and Ruales, J 1999. Processing of quinoa (Chenopodium quinoa, Wild): effects onin vitro iron availability and phytate hydrolysis. Int. J .Food Sci, Nutr.50:203-211.

[28] Wheeler E. L and Ferrel R. E (1971) A method for Phytic Acid Determination in wheat and wheat fractions .Cereal Chemistry,48,312-320

[29] WHO.1998. Complementary of young children in developing countries A review of current scientific knowledge WHO, Geneva, http://apps.who.int/bookorders/anglais/detart1.jspsession=1\&codlan=1\& codco $1=93 \& \operatorname{cod} c \mathrm{ch}=141$ 
[30] Wisal Hasan Idris Badi Effect of processing on Anti-Nutrition Factor and minerals Bioavailability of Sorghum .Faculty of Agric University of Khartoum, Sudan

Citation: O. E. Omara Ahmed, "Reducing Phytic Acid from Sudanese Sorghum Bicolor (F.G) Using Simple Technique Methods ", International Journal of Research Studies in Agricultural Sciences, vol. 3, no. 12, p. 1-7, 2017. http://dx.doi.org/10.20431/2454-6224.0312001

Copyright: (C) 2017 Authors. This is an open-access article distributed under the terms of the Creative Commons Attribution License, which permits unrestricted use, distribution, and reproduction in any medium, provided the original author and source are credited. 